\title{
COMPENSATORY HYPERTROPHY IN THE REMAINING TESTIS FOLLOWING UNILATERAL ORCHIDECTOMY IN THE ADULT RAM
}

\author{
J. K. VOGLMAYR* AND P. E. MATTNER \\ C.S.I.R.O., Division of Animal Physiology, \\ The Ian Clunies Ross Animal Research Laboratory, Prospect, N.S.W.
}

(Received 26th March 1968)

It is well known that in many mammalian species, including the sheep (Sundaram \& Stob, 1967), unilateral ovariectomy leads to compensatory hypertrophy in the remaining ovary and an ovulation rate equal to that of the two ovaries in the control animals (Parkes, 1966). However, it has not been conclusively established that analogous compensatory changes occur in the remaining testis following unilateral orchidectomy. Although it has been shown in the hemicastrated adult rat that the remaining testis enlarges (Grant, 1957) and the epididymal sperm reserve increases to that of the two epididymides in the intact animals (Smelser, 1933), observations on the hemicastrated rabbit (Edwards, 1940) and other species (see Parkes, 1966) are conflicting. Previous studies were limited because of the lack of a technique for accurately assessing production of spermatozoa and fluid by the testis. Such a technique has recently been developed for the conscious ram (Voglmayr, Scott, Setchell \& Waites, 1967) and has now been used to assess the function of the testis remaining after unilateral orchidectomy.

Nine Merino rams (3 to 5 years old, weighing 48 to $66 \mathrm{~kg}$ ) were kept for 4 weeks before and during the experimental period in a controlled environment $\left(21^{\circ} \mathrm{C}, 12 \mathrm{hr}\right.$ of light/day) and were maintained at constant body weight. In four rams one of the two testes was cannulated, allowing the collection of rete testis fluid and spermatozoa for a period of between 11 and 32 days (Voglmayr et al., 1967). The cannulated testes were then removed and, at the same time, the testis remaining in one of these rams ('hemicastrates') was cannulated and the collection of testicular secretion was continued uninterruptedly for a further 120 days. In the other three hemicastrates, the remaining testis was cannulated 100 days post-operatively and testicular secretion was collected over the following 20 days. At the same time, collections of spermatozoa and rete testis fluid were made from one testis of each of five entire, control animals. The testes were weighed after excision and portions of testis tissue were fixed in Susa and stained with Alcian blue Feulgen. The diameter of the seminiferous tubules was measured as described by Hay, Lindner \& Mann (1961).

By 120 days after hemicastration, the weight of the remaining testis had

* Present address: Department of Veterinary Physiology, The University of Sydney, Sydney, N.S.W., 2006, Australia. 
increased by $76 \%$ (S.E. $\pm 3.6 \%$ ) above the weight of the testis removed at hemicastration, and by $94 \%$ (S.E. $\pm 16.7 \%$ ) above the mean testis weight in the entire control animals (Table 1). Associated with the enlargement of the remaining testis was a greater rate of flow of rete testis fluid, whereas the concentration of spermatozoa in the fluid remained almost constant. The flow of rete testis fluid began to rise between the $32 \mathrm{nd}$ and $43 \mathrm{rd}$ day post-operatively and it continued to rise until about the 64th day so that the production of spermatozoa was almost twice that of the other testis before hemicastration. In both entire and hemicastrated rams the sperm output was in relation to testis weight and was approximately $17.5 \times 10^{6}$ cells/g testis/day. The mean diameter of the seminiferous tubules in the hemicastrates was significantly greater than in the entire animals and had increased from $181 \pm 6.5 \mu$ at hemicastration, to $238 \pm 5.9 \mu 120$ days post-operatively.

TABLE 1

EFFECT ON THE SECRETION OF FLUID AND OUTPUT OF SPERMATOZOA IN THE REMAINING TESTIS OF UNILATERAL ORGHIDEGTOMY IN THE ADULT RAM

\begin{tabular}{l|c|c|c}
\hline & Entire rams (fwe) & \multicolumn{2}{|c}{ Hemicastrated rams (four) } \\
\cline { 2 - 4 } & $\begin{array}{c}0 \text { to } 32 \text { days } \\
\text { pre-operatively }\end{array}$ & $\begin{array}{c}100 \text { to } 120 \text { days } \\
\text { post-operatively }\end{array}$ \\
\hline Testis weight (g) & $174 \cdot 0 \pm 8 \cdot 35$ & $192 \cdot 0 \pm 21 \cdot 2$ & $338 \cdot 0 \pm 26 \cdot 7 * *$ \\
$\begin{array}{c}\text { Fluid secreted } \\
(\mathrm{ml} / \text { testis/day) }\end{array}$ & $28 \cdot 3 \pm 2 \cdot 67$ & $30 \cdot 2 \pm 4 \cdot 1$ & $53 \cdot 2 \pm 4 \cdot 6^{* *}$ \\
$\begin{array}{c}\text { Sperm concentration } \\
\left(10^{6} \text { cells/ml }\right)\end{array}$ & $122 \cdot 0 \pm 18 \cdot 1$ & $111 \cdot 0 \pm 26 \cdot 2$ & $117 \cdot 1 \pm 15 \cdot 7$ \\
$\begin{array}{c}\text { Sperm output } \\
\left(10^{9} \text { cells/testis/day) }\right.\end{array}$ & $3 \cdot 26 \pm 0.59$ & $3 \cdot 10 \pm 0.53$ & $6 \cdot 04 \pm 0 \cdot 44^{*}$ \\
\hline
\end{tabular}

Values are the means \pm S.E. for one testis per animal. Numbers of rams are shown in parentheses.

$$
* P<0.01 ; * * P<0.001 \text {. }
$$

Earlier observations in hemicastrated dogs and rabbits revealed that the compensatory enlargement of the remaining testis is attributable to an increase in the diameter of the seminiferous tubules (Ribbert, 1890). In the present study with adult rams, the expansion of the seminiferous tubules could account almost entirely for the increase in the testis weight. Further studies relating to the mechanism underlying the effect of hemicastration would be valuable.

We are grateful to Dr G. M. H. Waites and Dr R. G. Wales for helpful advice.

\section{REFERENCES}

EDWARds, J. (1940) The effect of unilateral castration on spermatogenesis. Proc. R. Soc. B, 128, 407. Grant, J. H. (1957) The effects of unilateral orchidectomy on the rat testis. Proc. Soc. Study Fert. 8, 27. HAY, M. F., Lindner, H. R. \& MANN, T. (1961) Morphology of bull testes and seminal vesicles in relation to testicular androgens. Proc. $R$. Soc. B, 154, 433. 
PARkes, A. S. (1966) Marshall's Physiology of Reproduction, Vol. 3, Chap. 24. Longmans, London.

RibBert, H. (1890) Über die kompensatorische Hypertrophie der Geschlechtsdrüsen. Virchows Arch. path. Anat. Physiol. 120, 247.

SMELSER, G. K. (1933) Compensatory hyper-activity of the testis following unilateral castration. Anat. Rec. 57, Suppl. 28.

Sundaram, S. K. \& Stob, M. (1967) Effect of unilateral ovariectomy on the reproduction and induced ovulation in the ewe. F. Anim. Sci. 26, 374.

Voglmayr, J. K., Scott, T. W., Setchele, B. P. \& Waites, G. M. H. (1967) Metabolism of testicular spermatozoa and characteristics of testicular fluid collected from conscious rams. 7. Reprod. Fert. 14, 87. 